\title{
The Female Artist within the Framing Narrative in The Tenant of Wildfell Hall
}

\author{
Farideh Pourgiv \\ Sara Ebrahimi Rahmati \\ Department of Foreign Languages and Linguistics, Faculty of Humanities and \\ Literature, Shiraz University, Eram Campus, Eram Street 7194684795, Shiraz, Iran \\ e-mails: fpourgiv@rose.shirazu.ac.ir \\ abi_bikaran2@yahoo.com
}

\begin{abstract}
Through the use of narrative analysis of The Tenant of Wildfell Hall, it is argued in this paper that by introducing a female artist Bronte is posing questions regarding the experiences of the middle class women of the Victorian era, thus showing how much they were allowed to express their desires and emotions. Bronte presents a female artist who is forced to choose between her role as a wife and her role as an artist. The use of a journal in this novel makes it a counterplot in which female maturity is not equated with marriage, but with the heroine's rejection of her role as a wife, for though Helen's character develops through her experience in courtship and marriage, it is her flight and rejection of the angel that empowers her to be born as an artist.
\end{abstract}

Key words: framing narrative, The Tenant of Wildfell Hall, female artist, Victorian novel

"The rise of the novel", Armstrong (1987) writes in her political history of the novel, "hinged upon a struggle to say what made a woman desirable” (pp. 4-5). During the eighteenth and nineteenth centuries--unlike the seventeenth century in which conduct books were written merely for men--numerous conduct books were written for women in order to make them desirable to men, or in other words, to make them marriageable. It was as if the portrayal of a female figure, as Armstrong (1987) claims, had become the center of "the struggle among competing ideologies" of the period (p. 5). Following the tradition of the conduct books, authors like Richardson, began to create their idea of womankind through the newly developing form of fiction, which was later established as novel. "The 
conduct book ideal of womanhood," Armstrong (1987) writes, "provided the ideal against which novelistic representations of women asserted themselves as being more true to life" (p. 252). Novels that in Richardsonian tradition concentrated on courtship and marriage, introduced the more realistic domestic woman. In this way Victorian fiction, as Armstrong (1987) also mentions "took on the task of re-tailoring the representation of women to indicate that each individual had slightly different desires” (p. 252). Yet to exalt the domestic woman over and above her counterparts, they had to evaluate her behavior according to a set of moral standards. Thus the domestic woman could be differentiated from the ideal woman only up to the place that she would not fall to the level of the demonic woman.

Coventry Patmore's The Angel in the House was among those conduct-books, which were very influential during the nineteenth century. Patmore's phrase provided a suitable name for an ideology that became, as Siv Jansson (1998) says, "a part of the iconography of the nineteenth century" (p. 31). To show the problematic conflicts at the center of such ideal image of womanhood--an image which was subsequently given the name the Angel in the House--and to argue against the right of society to expect such an impossible standard, some novelists employed a similar language, to introduce female desire within the image of the desirable woman. Jansson (1998) regards The Tenant of Wildfell Hall as one of those "rebellious texts" that use images of the religious women "as a ploy to write into their texts their own radical reassessments of the dominant culture” (p. 32). This "redefinition of desire," Armstrong (1987) argues was "a decisive step in producing the densely interwoven fabric of common sense and sentimentality that even today ensure the ubiquity of middle-class power" (p. 5).

Narratology has played an important role in the analysis of novels; Warhol (1989) states, "Although narratology itself has not addressed gender, and though gender has not yet been a factor in many narratological studies of the level of discourse, structural analysis on the level of story has proven very useful for feminist criticism" (p. 5). Though character is one of the most influential elements of each story, the study of character has not been developed as much as other elements of narrative. Character can be studied from several aspects and in different levels. It is often, as Toolan (1988) mentions "what most powerfully attracts the readers to novels and stories," yet most critics believe that to systematic analysis, it seems "the 
least amenable" element of the narrative and therefore within most narratological studies, character "remains relatively neglected" (p. 80). Rimmon-Kenan (1983) introduces the key approaches to narrative fiction focusing on issues such as events, time, focalization and narration. Since characters are represented through words and actions, the question of the existence of character inevitably leads to two basic problems. The first problem as Rimmon-Kenan (1983) classifies in her Narrative Fiction, is the distinction of character from the text, shifting between the mimetic theories of character "equated with people" and semiotic theories of character as merely words "dissolved in textuality" (p. 33). The second problem is the distinction of character from action. "Being or doing," is the other important question in the study of character, to which critics have not come to a clear conclusion yet. But the effort to find an answer to such questions has opened the way for new studies of character and narrative fiction.

The answer to the question of "being or doing" also illuminates one of the most important differences between the twentieth and nineteenth century approaches to character. In the nineteenth century, characters of narrative fiction were studied as real people, while formalists and structuralists of the twentieth century mostly tried to define character in terms of action. On the other hand, the distinction between character and action has always been a problem in literary criticism; the twentieth century insistence on studying characters as performers rather than independent beings has also been regarded as a reaction to Victorian emphasis on lifelike characters. Toolan (1988), for example, considers the development of such studies of character as partly "a widespread reaction in mid-twentiethcentury literary study to any literary criticism and analysis which tended to assimilate characters in literature to real people," especially against the "heavy emphasis on character, the bourgeois self-determining Subject, found in both nineteenth-century British novels and traditional literary criticism about them" (p. 80).

One of the most notable elements of the The Tenant of Wildfell Hall is its complicated framing device. Gilbert Markham's epistolary account of his relationship with Helen Graham that surrounds the much lengthier diary account of her first marriage and flight from her husband has often been judged to be unusual and inadequate. Like Wuthering Heights, The Tenant of Wildfell Hall has been variously criticized for framing a female story within a male framework. The framing narrative of The Tenant of 
Wildfell Hall, which is narrated by the male hero, is divided into two parts: the opening section and the ending of the novel with Helen's journal in the middle. Though relatively a short part, it is constructed with much economy and its condensed narrative can be compared to a miniature picture of all that is going to be implied in the novel. It is only in this section that the heroin appears as a professional artist. The opening section of the framing narrative somehow functions like a mirror held in front of the framed narrative. While it seems to contain merely puzzling elements whose realities are going to be discovered in the next sections, it later proves to have contained the most revealing evidences and clues to the whole novel. It is, in other words, an ending which has come in the beginning. This paper focuses on the opening of the novel as the most revealing part of the narrative suggesting that the author's employment of the artistic image can be considered as a strategy for introducing female desire. For, unlike the angelic role which controlled and limited female desire, by imposing what the patriarchal society desired a woman to be, the image of the woman artist librated female desire by speaking of what woman desired to be.

While the opening of The Tenant of Wildfell Hall has often been admired as the most attractive part of the novel, critics have mostly disapproved of the ending. They have found little advantage in the mingling of Helen's voice through her letters with Gilbert's account of the story. It is also in this section that the woman artist leaves to appear once more as the woman savior, and finally chooses to become a wife instead of a professional artist.

One of the most significant features of The Tenant of Wildfell Hall is the representation of the heroine as a professional artist, even though for a short period of her life. All members of the Bronte family were interested in art and all practiced painting and drawing to some degree and this interest is also reflected in the Bronte novels. "From Jane Eyre's unearthly drawings to Helen Huntingdon's canvases," says Felicia Gordon (1989), "painting functions in the novels as an important metaphor for revealing artistic ambition and suppressed personality" (p. 118). Yet the example of a woman whose art turns to be her profession is rare even among the Bronte sisters. In Jane Eyre for example, the heroine's art is used only as a means of courtship and self-expression not as a profession. But in The Tenant of Wildfell Hall, Anne Bronte has portrayed Helen as a woman artist whose art, not only empowers her to earn a living, but also provides her the 
opportunity to run away from her abusive husband. Leaver (2007) believes, "The Tenant of Wildfell Hall, angry, restless and confrontational, functions as a centrally important document that makes a significant contribution to what is often sometimes simplistically called the Woman Question" (p. 228). Ward (2007) states, "In its stark portrayal of a dysfunctional, abusive marriage, the Tenant shattered the pretenses of marital harmony so beloved of many Victorians" (p. 151).

Critics like Shaw (2001), believe that the Tenant is a Kunstlerroman; Shaw admires Bronte as being the rare example of woman writing a Kunstlerroman and based on this assumption, explains how both narrative technique and characterization, support this idea. Shaw (2001) begins her argument by explaining the problem of the Victorian society's interference in the development of the artist, believing that "an outgrowth of the ambivalence that has long been an element of the artist's image," (p. 9) was still influential in the nineteenth century. The image of the artist, like the image of woman portrayed in the fiction, had a dual representation of evil magician and the mighty creator. "For the Victorians," Shaw (2001) explains, "the gender variable seems only to exacerbate this sense of ambivalence. Women were often regarded as lacking the mighty attribute and possessing the evil one" (p. 9). Thus, denied the role of the mighty creators, women were often assigned the negative role within the Victorian ideology. The fictional representation of the woman artist was also problematic. The male form of Bildungsroman and Kunstlerroman failed in the representations of the female artist because their application to women's experiences proved to be fundamentally inadequate. As O'Gorman (2002) states, "Victorian women were not accustomed to choosing a vocation; womanhood was a vocation in itself" (p. 73).

Abel, Hirsch, and Langland (1983) suggest that the traditional definition of the Bildungsroman acknowledges the influence of a variety of psychological, historical, and cultural variables, but it ignores gender as an important factor in the development of the protagonist. The traditional Bildungsroman, they say, is based on the assumption "that society constrains men and women equally" (p. 6). Yet the fundamental differences in the upbringing of Victorian men and women must not be disregarded. Unlike men, women had a much more limited opportunity of real experience. Men could travel alone while a respectable woman always needed some kind of company; or men could engage in sexual encounters that would have utterly destroyed a woman's reputation. Thus, as Abel, 
Hirsch, and Langland (1983) also suggest, Victorian propriety restricted women to the degree that they were often prevented from engaging in the "real education" that was essential to the development of an artist. They believe that "the sex of the protagonist modifies every aspect of a particular Bildungsroman: its narrative structure, its implied psychology, its representation of social pressures" (p. 5).

Believing that the male version of Bildungsroman cannot be applied to the women's development, some feminist critics began to search for a new model of Bildungsroman, capable of introducing the progress of female protagonist. Susan Fraiman (1993) suggests that the typical development of a woman is in the form of "endless negotiation of a crossroads," as opposed to "linear development" which is presented in male Bildungsroman" (p. x). She states that women authors make use of traditional Bildungsroman model and then decenter it by including alternative accounts of maturation and development within the same work; in other words, they write "other stories" which is "rewriting the heroine's rise to happy maturity as a history of obstruction, imposition, and loss" (p. x). According to Fraiman (1993), women authors of Bildungsroman produce both a conventional plot and one or more counterplots. The conventional plot depicts courtship as education and marriage as vocation and "equates female maturity and gratification with the married state" (p. 16). On the contrary, the counterplots not only question such an equation, but also introduce other versions of female development. This pattern, Shaw (2001) believes, "can be quite aptly applied to Wildfell Hall, for while the novel does end in marriage, it also questions the ideology which equates female maturity with a successful courtship" (p. 12).

The characteristics of the heroine of the female form of Kunstlerroman is also different from the male version, for though the female protagonist shares the rare talent and superior judgment of the male artist, her character, her conflicts, and her reward radically differ from those of the male artist. Linda Huf (1983) tries to address these differences and identifies some central points of contrast between the female and male artists. One of the evident differences between male and female artistic protagonists is the personality of the artist. Anne Bronte's heroine possesses the "masculine traits" that Huf (1983) demonstrates as the first characteristic of the woman artist. Another point of contrast between male and female artists is in the "artist's ruling conflict" that is, the conflict of the male artist centers on the anxiety between life and art. He must choose between the sensual and the 
spiritual, but as Huf (1983) explains, the artist heroine "must choose between her sexuality and her profession, between her womanhood and her work" (p. 5). The absence of a muse is another element that differentiates the artist heroine from the artist hero. The artist hero is mostly depicted as needing a female muse in order to create, while the woman artist not only has no male muse but also suffers from male intrusion. The men of the heroine's life are usually portrayed as the constant reminders that her artistry violates her conventional role and thus the role of man is depicted as discouraging rather than inspiring for the woman artist. The differences that Huf identifies are all gender-based and inevitably lead to the conclusion that "the woman's artist novel calls for the smashing of the man-forged manacles on her sex" (p. 10).

Many of the characteristics of the female version of Kunstlerroman are found in The Tenant of Wildfell Hall. Shaw (2001) believes that by engaging her heroine with the traditional image of the artist, Bronte has addressed not only the narrative pattern of the English Kunstlerroman and the artistic stereotype inherited from the Renaissance and continued by contemporary critics such as John Ruskin, but has also claimed "certain narrative elements and certain attributes for her artist-heroine," that reveal "fundamental differences in the conflicts faced by male and female artists" (p. 14).

Thornfield hides a mad woman in its attic, the Wuthering Heights is haunted by Catharine's soul, but it is a woman Artist who resides in the Wildfell Hall. The strangeness and horror of the Wildfell Hall is only created through a shocking reality: a lonely woman with her son, who tries to earn a living by painting landscapes. "The Brontes' mature novels," Gordon (1984) asserts, "show strong traces of the creative adaptation of Gothic elements" (p. 91), and Anne Bronte, like her sisters, also adopts gothic elements in the opening section of her novel. Her employment of the gothic has been widely compared and contrasted to Emily's in the Wuthering Heights. "Anne Bronte's Wildfell Hall", as Gordon (1984) also suggests, "is another Gothic, half ruined", mansion, yet unlike Wuthering Heights, it is "domesticated and emptied of the supernatural" (p. 91). Since almost all the gothic elements of the novel are concentrated around Helen Graham (as the woman artist), this combination of the gothic and realism can best reflect the sharp contrast between the notion of the aesthetic woman with the patriarchal ideologies of the Victorian society. This idea is highlighted in the second chapter of the novel, when to reach the woman 
artist, Gilbert leaves "the more frequented regions" and proceeds "to mount the steep acclivity of Wildfell, the wildest and the loftiest eminence" in the neighborhood (Bronte, 1998, p. 19). The gloomy and horrifying atmosphere of the Wildfell Hall, which is surrounded by "rough and stony" fields, filled with "relics of more savage wildness" is stressed in Gilbert's description of the place. "Near the top of this hill", Gilbert illustrates, "stood Wildfell Hall, a superannuated mansion of the Elizabethan era built of dark grey stone-venerable and picturesque to look at, but doubtless cold and gloomy enough to inhabit" (p. 19). The woman artist lives in a "too lonely, too unsheltered situation-only shielded from the war of wind and weather by a group of Scotch firs, themselves half blighted with storms, and looking as stern and gloomy as the Hall itself" (p. 19). Wildfell Hall seems quite a proper place for the residence of the woman artist, whose existence was a wild and shocking reality for the Victorian society.

Rejecting her role as the angel in the house, Helen Graham appears as the woman artist in the framing narrative. Gilbert's first impression of the heroine, evidently suggests that Mrs. Graham of the framing narrative is far different from the angelic Helen Huntingdon of the framed narrative. He finds her features "unexceptionable," yet thinks that she possesses "no very soft or amiable temper" (p. 15). She is no more the representation of the conventional desirable woman: "I would rather admire you from this distance, fair lady", Gilbert thinks, "than be the partner of your home" (p. 15). When asked his opinion of the mysterious Mrs. Graham, Gilbert Markham, acknowledges her beauty but pronounces her "too hard, too sharp, too bitter for my taste" (p. 39). According to the mentioned feministic definitions of Kunstlerroman, the female artist is forced to choose between her role as a wife and her role as an artist, and this is exactly what happens in the Wildfell Hall. As soon as Helen rejects her role as an angelic wife, the woman artist is born. At the beginning of Gilbert's narrative, Anne shows how the image of the woman artist appears less desirable in comparison to the conventional images of womanhood defined by the society. Yet, as Gilbert's point of view, which represents the male perspective, gradually changes toward Mrs. Markham, the woman artist precedes the angelic woman as the desirable image of womanhood.

In chapter five, titled The Studio, Gilbert is both attracted and amazed by Mrs. Graham's studio, recording his first entrance to the Wildfell Hall, Gilbert writes: "to our surprise, we were ushered into a room where the first object that met the eye was a painter's easel, with a table beside it 
covered with rolls of canvass, bottles of oil and varnish, palette, brushes, paints, \&c [sic]" (p. 42). Approaching to observe her painting, Gilbert confesses that he has surveyed it "with a greater degree of admiration and delight than I cared to express" (p. 42). In the following chapter, Gilbert finds himself unintentionally enchanted by Mrs. Graham's “eloquence, and depth of thought and feeling", in conversation (p. 48). As he starts to think "that, after all, it would, perhaps, be better to spend one's day with such a woman" (p. 48), the narrative succeeds in modifying and reforming the image of the desirable woman within the male perspective.

Soon, Gilbert finds "the playful nonsense" of Eliza Millward, (his former object of desire) "wearisome" to his soul, and feels himself, "drawn by an irresistible attraction to that distant point where the fair artist sat and plied her solitary task" (p. 62). At the end of the opening section, with Gilbert's defense of Helen Graham against all the gossip and prejudice of people of the village, the conventional image of the desirable woman is replaced by the image of the woman artist in the mind of the male hero. It is as if Anne Bronte has employed Gilbert's framing narrative as a strategy to internalize the newly reproduced image of the desirable woman within the masculine frame of mind.

The romantic plot of the framing narrative is broken by Gilbert's false assumption of a love affair between Helen Graham and Fredrick Lawrence. To restore Gilbert's former opinion of her, Helen offers him her journal, which is according to Fraiman (1993) an example of "other stories" or "counterplot" employed in female Kunstlerroman. "This insertion," Shaw (2001) suggests, "not only introduces the less than 'happily ever after' as a possibility, but also introduces an alternative version of female development in the form of a Kunstlerroman" (p. 12). Within this perspective, the journal is regarded as a counterplot in which female maturity is not equated with marriage, but with the heroine's rejection of her role as a wife; for though Helen's character develops through her experience in courtship and marriage, it is her flight and rejection of the angel that empowers her to be born as an artist.

The journal reveals the history of the heroine's development as an artist. Helen enters the story as a young girl who employs painting as a means of self-expression and courtship. Helen's painting is at the service of desire fulfillment for both her and Arthur. It makes Helen visible and enables her to attract and win the attention of her desirable male figure. Such application of art is revealed several times in the journal. A fine 
example is when Helen competes with Annabella Wilmot for Huntingdon's attention: "though he likes music, and she is an accomplished musician, I think I am right in affirming that he paid more attention to my drawings than to her music" (p. 146). Another revealing evidence of the connection between art and courtship is in Helen's effort to copy Arthur's image. It can be considered one of the concealment strategies, which is employed by Anne Bronte to introduce female desire. It also reflects the fact that Victorian prohibition against the open expression of female desire forces Helen to reflect her passion within portfolios of "unfinished sketches" which are concealed at the backs of her paintings (p. 151). Arthur pays attention to Helen's art, only with the purpose of approaching her. Besides, his interest in Helen's art is also shown to satisfy his narcissism. He takes pleasure in discovering that he has been Helen's main object of desire. All these scenes Shaw (2001) explains, "tend to reduce her art to a mere accomplishment with which she can attract a man" (p. 15). Here, Anne Bronte has tactfully employed art to introduce female desire since painting is obviously used by Helen to express her desire as a young woman, for "despite being hidden behind a public facade", Shaw (2001) also suggests, "Helen's new aesthetic space eventually exposes what she had concealed" (p. 13). Though there has been much emphasis on woman's art as a means of courtship, it can be argued that Anne Bronte, as Fraiman (1993) suggests, employs "other" methods to reject the patriarchal interpretation of woman's art as merely mirroring and expressive. Helen as the heroine of Kunstlerroman, rejects this notion by fighting against the male intrusion.

This intrusion, which is stressed in The Tenant of Wildfell Hall, is associated with another element of Kunstlerroman: the absence of the muse. According to Huf's (1983) definition of the Kunstlerroman, images of masculine corruption and of Helen's fragile control over it can be studied as the male intrusiveness in the development of the woman artist. Russell Poole (1993) has also examined male behavior toward the woman artist in the novel and admits that it is characterized by "intrusiveness, appropriation, and violence," which are most significantly present in "a series of scenes in which sundry men impinge on her artistic activities" (p. 860). Poole (1993) argues that Helen is at first "initially pleased" by Arthur's admiring gaze, yet soon she realizes that his regard "is a twoedged sword" (p. 861). It is at first a hunter's gaze who is merely after his desire fulfillment. Later, Arthur by "complacently gazing" at the 
representation of his own face, treats her art merely as a "mirror in which the male is reflected" (p. 861), and finally in the climactic scene in which he destroys her painting materials, Helen finds herself "tyrannized over by [Arthur's] bright, laughing eyes" (Bronte, 1998, p. 173) as he "held the candle in my face and peered into my eyes with looks and laughter too insulting to be borne"(p. 371).

The journal follows Helen's fight against the male gaze as she returns the intrusive violence upon the violator: "To show him how I valued it [Arthur's miniature portrait], I tore it in two, and threw it into the fire" (p. 152). This reaction, which Arthur is not prepared for, turns his hunting and intrusive gaze into a bewildered look: "he stared in mute amazement" (p. 152). Similarly, she returns the gaze of her prospective seducer, by snatching up her palette knife and holding it against him and looking "as fierce and resolute as he" (p. 343). Through this startling behavior, Hargrave's intrusive gaze is transformed into a bewildering one as Helen describes the scene: "he stood and gazed at me in astonishment" (p. 343). With a face "blanched with anger," Hargrave calls Helen the most "unnatural" woman he has ever beheld (p. 343).

As soon as the vocation assigned to Helen by her culture disintegrates, a major transition initiates in her development as an artist. As Arthur's development as a rake, gradually shatters Helen's belief in the socially imposed role of the angel in the house, the woman artist is empowered to appear under the socially acceptable pretext of Helen's maternal duty in protecting her son against her husband. "The circumstance", Shaw (2001) suggests, "allows Helen to rewrite her artistic ambition as self-sacrificial duty: it is to protect her son that she contemplates making art her livelihood" (p. 15). Succeeding as her own midwife, Helen transfers from an amateur artist into a professional one. As Helen enters the framing narrative, Shaw (2001) mentions, "her private audience becomes a public one. Her pastime becomes a profession" (p. 15). Thus Ann Bronte has been able to introduce a woman artist whose talent is genuine in subverting the dominant ideology of Ruskin.

The conclusive part of the novel however, is ambiguous regarding the destiny of the female artist. When Helen leaves Wildfell Hall to nurse Arthur Huntingdon on his deathbed, the woman artist disappears. As Mrs. Huntingdon, Helen seemingly embodies the role of angelic savior once more. Yet with the death of Arthur as the original initiator of the angelic mission, the angle in the house finally fades away and the heroine is 
librated to live as an independent woman. Shaw (2001) believes that with Helen's second marriage to Gilbert Markham at the end of the novel, "the female artist gives way to the wife," representing the fact the artist-heroine must face the binary choice of being an artist or a wife, not both (p. 16). Helen actually leaves Mrs. Graham as the image of professional artist of the opening section, in the mysterious Wildfell Hall and after a temporary residence in Huntingdon's house, returns to the house she has been brought up in to finally become Helen Markham. The novel does not provide any information about Helen's artistic activities after her second marriage. Yet it could be argued that it is not Helen's second marriage but her financial security that makes her to give up art as profession. As the romantic plot reaches its pinnacle with the union of Helen and Gilbert, the counterplots of the "other stories" are overwhelmed by the revival of the conventional. This structure Shaw (2001) suggests, "reveal that a nineteenth-century woman who attempts to grow up according to a pattern other than the one assigned to her by her culture finds her way obstructed" (p. 16). If the social roles of the nineteenth century, (such as the angel, the savior and the saint) clarify the way Victorian society defined the ideal of womanhood as men desired them to be, through male characterization, Anne Bronte ventures to introduce female desire by projecting what a woman wants within the image of the desirable man. The framed narrative is mostly concerned with the desirable woman, yet the framing narrative reflects the needs of the desiring woman.

\section{REFERENCES}

Able, E., Hirsch, M., \& Langland, E. (Eds.). (1983). The voyage in: Fictions of female development. Hanover: University Press of New England for Dartmouth College.

Armstrong, N. (1987). Desire and domestic fiction: A political history of the novel. Oxford: Oxford University Press.

Bronte, A. (1998). The tenant of Wildfell Hall. New York: Oxford University Press.

Fraiman, S. (1993). Unbecoming women: British women writers and the novel of development. New York: Columbia University Press.

Gordon, F. (1989). A preface to the Brontes. London: Longman.

Huf, L. (1983). Portrait of the artist as a young woman: The writer as heroine in American literature. New York: Frederick Ungar. 
Jansson, S. (1998). The tenant of Wildfell Hall: Rejecting the angel's influence. In A. Hogan, \& A. Bradstock (Eds.), Women of faith in Victorian culture (pp. 31-47). London: Macmillan.

Leaver, E. (2007). Why Anne Bronte wrote as she did. Bronte Studies, 32, 227-243.

O'Gorman, F. (Ed.). (2002). The Victorian novel. Oxford: Blackwell.

Pool, R. (1993). Cultural reformation and cultural reproduction in Ann Bronte's The Tenant of Wildfell Hall. Studies in English Literature 1500-1900, 33, 859873.

Rimmon-Kenan, S. (1983). Narrative fiction. London: Routledge.

Shaw, K. L. (2001). Wildfell Hall and the artist as a young woman. West Virginia University Philological Papers, 48, 9-17.

Toolan, M. (1988). Narrative: A critical linguistic introduction. London: Routledge.

Ward, I. (2007). The case of Helen Huntingdon. Criticism, 49, 151-182.

Warhol, R. R. (1989). Gendered interventions, narrative discourse in the Victorian novel. New Brunswick: Rutgers University Press. 